\title{
The Same Intestinal Inflammatory Disease despite Different Genetic Risk Factors in the East and West?
}

\author{
Rashid N.S. Lui Siew C. Ng \\ Institute of Digestive Disease, Department of Medicine and Therapeutics, Faculty of Medicine, \\ The Chinese University of Hong Kong, Hong Kong SAR
}

\section{Key Words}

Crohn's disease - Ulcerative colitis · Asia - Genetics .

Epidemiology · Phenotype

\begin{abstract}
Background: Inflammatory bowel disease (IBD) is a chronic inflammatory disease with unknown etiology. It is likely caused by a complex interplay between genetic, immunologic and environmental factors. Although IBD is still relatively uncommon in Asia, a multitude of studies have shown that it is an emerging disease around the world. Recent insights have highlighted both the similarities and differences amongst Asian and Western IBD patients. Summary: The annual incidence of IBD in the East is still low compared with the West, but there are differences between different regions of Asia. Time trend studies have shown that the incidence of IBD is on the rise. Some notable differences in the clinical manifestations of IBD between the East and West have also been noted. 'Westernization' of lifestyle may encompass various social and environmental changes that account for the emergence of IBD in our population, although genetics also plays a role in disease pathogenesis. Diagnosis and treatment challenges include limited access to medical care in certain areas, limited availability and high cost of
\end{abstract}

medications, lack of insurance reimbursement, paucity of multidisciplinary teams for the management of complicated IBD cases, and a high prevalence of endemic infections. Currently, the risk of colorectal cancer is lower in the East than in the West, but cancer rates will likely approach that of the West in the future as the prevalence of IBD continues to rise. Key Messages: Measures to improve access to diagnostic tools, increase the availability of medication, and provide adequate multidisciplinary care for IBD patients will become increasingly important in Asia. Differences between the East and West will provide a unique opportunity for global collaboration in basic and clinical research to further our understanding of the disease entity and also provide more locoregional data to healthcare providers and policymakers to make informed decisions and policy changes when tackling the rising burden of IBD in Asia.

(c) 2016 S. Karger AG, Basel

\section{Epidemiology}

Until recently, population-based epidemiologic data from countries in Asia were scarce. Data from a prospective, population-based study conducted in the Asia-Pacific region from 2011 to 2012 showed that the crude an-

\section{KARGER}

E-Mail karger@karger.com www.karger.com/iid
(C) 2016 S. Karger AG, Basel

2296-9403/16/0012-0078\$39.50/0
Siew C. Ng

Institute of Digestive Disease Room 94020, 7/F

Lui Che Woo Clinical Sciences Building, Prince of Wales Hospital

Shatin NT, Hong Kong (SAR)

E-Mail siewchienng@cuhk.edu.hk 
nual incidence of inflammatory bowel disease (IBD) was 1.37 per 100,000 individuals [1]. This varied amongst different regions with the highest incidence in urbanised cities such as Guangzhou, China (3.44 per 100,000 individuals), followed by Hong Kong (HK) (3.06 per 100,000 individuals) and Macau (2.2 per 100,000 individuals). The lowest incidence was reported from Xian, China ( 0.54 per 100,000 individuals). Besides geographical differences, in multiracial countries such as Malaysia and Singapore, Indians appear to be more susceptible to ulcerative colitis (UC) than their Chinese and Malay counterparts within the same country $[2,3]$, which supports the genetic underpinning of the disease. Although still relatively uncommon in Asia as compared with the West, various time trend studies have shown that the incidence of IBD is on the rise [4]. In HK, from 1990 to 2001, the incidence of UC and Crohn's disease (CD) rose from 0.8 to 1.2 and from 0.4 to 1.0, respectively [5]. The incidence of IBD in HK has risen by almost threefold in the past two decades.

In the past few decades, longitudinal studies from the West, where the incidence of IBD has stabilised, have lent insight into the pattern of IBD emergence. Initially, when the overall incidence of IBD is low, UC emerges first while $\mathrm{CD}$ remains rare. Over time, the incidence of $\mathrm{CD}$ ultimately matches and may even exceed that of UC [6]. Reflecting this trend, in a comparative study, the UC:CD ratio was approximately 2.0 in Asia and 0.5 in Australia [1]. Various studies across Asia have shown that the $\mathrm{UC}: \mathrm{CD}$ ratio is narrowing $[7,8]$. Although there is increased disease awareness, access to medical care and improved diagnostic tools may play a role in this epidemiological shift [9]; these factors alone are unlikely to account for the entirety of such changes. Therefore, the influence of lifestyle, environmental changes, and genetic susceptibility [10] likely play an even more significant role.

The overall prevalence of IBD in Asia may be difficult to estimate as national registries are lacking in most Asian countries [11]. According to the Japanese nationwide registration system of patients with intractable diseases that includes IBD, the age-standardised prevalence of UC in 2005 was 63.6 per 100,000 individuals and that of CD was 21.2 per 100,000 individuals [12].

\section{Disease Phenotype}

Clinical manifestations of IBD in Asia resemble those of the Western population, but with some notable differences, such as a higher prevalence of males with $\mathrm{CD}$, more ileocolonic $\mathrm{CD}$, less familial clustering, lower surgical

The Same Intestinal Inflammatory

Disease in the East and West? rates, especially in UC, and less extra-intestinal manifestations, including a lower frequency of primary sclerosing cholangitis $[7,9]$. The early course of disease in patients with IBD in Asia was shown to be comparable with that of the West, with CD patients frequently progressing to complicated disease and having an accelerated use of immunosuppressants [13]. The disease severity in Asian CD patients was also comparable to that reported in Australia, with an even higher rate of penetrating disease and perianal disease at diagnosis noted in Asia [1]. This is contrary to previous notions that IBD runs a milder disease course in Asia [14].

Similar to the West, Asian patients diagnosed with CD were more likely to be younger (median age 34 years) than those with UC (median age 42 years). The peak age at diagnosis of CD was 20-24 years, with a second smaller peak at 40-44 years. The peak age at diagnosis of UC was 30-34 years [1]. A second peak after 50 years of age is less common in Asian patients [15].

Studies in Asia have reported a lower rate of family history of IBD (0-3\%) than studies from the West (10-25\%) $[1,4]$. A study from Korea showed an increase in the incidence of a positive family history from $1.3 \%$ in 2001 to $2.7 \%$ in 2005 , which parallels with the increased incidence of IBD [16]. It is likely that in the foreseeable future, the rate of a positive family history will increase as the incidence and prevalence of the disease increase over time. These differences between Asian and Western IBD are likely to be multifactorial and may be secondary to differences in genetic background, environmental exposure, such as diet and intestinal flora, and the duration of disease [9]. The exact contribution of these factors to disease expression remains to be determined.

\section{Risk Factors}

Environmental risk factors are likely to play a major role in disease development. The two strongest environmental associations for IBD, cigarette smoking (where smoking has been consistently shown to be a risk factor for CD but is protective for UC [17]) and appendectomy, cannot fully account for the variations in incidence and prevalence of IBD. It is postulated that other socioeconomic factors such as urbanisation of societies, changes in diet, antibiotic use, improved hygiene, microbial exposures, and pollution are all implicated in the development of IBD [10].

This 'Westernization' of lifestyle may partially account for the emerging trends in IBD in the Asia-Pacific 
region where economic development and industrialisation have been unprecedented [18]. An example would be a more Westernised diet, where an increased intake of refined sugar, fatty acids, sweeteners and meat may increase the risk for IBD. Conversely, an increased intake of fruits, vegetables, and fibres may decrease this risk [19, 20]. In addition, in the first, large population-based casecontrol study conducted in the Asia-Pacific region, breast-feeding for $>12$ months was protective for the development of CD and UC in childhood. Novel protective factors suggested in this study include childhood contact with pets and consumption of tea and coffee [21]. Interestingly, an inverse association between antibiotic use and the development of CD suggests that antibiotics may not be a contributing factor to the rising incidence in Asia. All in all, this implies that it is not only the exposure to environmental risk factors, but also the timing of such an exposure which would be critical in modulating the risk of UC and CD later on in life. The importance of these childhood immunological, hygiene, and dietary factors, and their downstream effect on the intestinal microbial milieu cannot be overstated [11]. Indeed, a dysbiosis in IBD patients in Asia with a decrease in butyrateproducing bacterial species was observed [22], a finding similar to recent studies in Caucasian patients with UC [23].

\section{Genetics}

To date, more than 160 independent genetic susceptibility loci have been identified for IBD using large-scale genome-wide association studies (GWAS) in European cohorts [24]. A recent study using a trans-ancestry approach which included East Asians, Indians, Iranians, and Caucasians showed that first, 38 novel susceptibility loci were identified. Secondly, in general, a shared genetic risk existed across populations. Thirdly, genetic heterogeneity was shown, where differences in allele frequency, i.e. genetic variants in nucleotide-binding oligomerization domain-2 (NOD2), were not detected in Asians, and effect size, i.e. a much stronger effect on disease risk in East Asia for variants in tumour necrosis factor superfamily, member 15 (TNFSF15) as compared with Caucasians [25]. This confirms previous findings that NOD2 and autophagy-related protein 16 (ATG16L1) have a minimal role in East Asian CD [26-28].

In Asia, a smaller-scale GWAS from Japan showed new susceptibility loci for UC on the major histocompatibility complex region [29]; Other genes include variants in cytotoxic T-lymphocyte antigen-4 (CTLA-4) and tumour necrosis factor alpha-308 (TNF-308) [30].

Another smaller-scale GWAS from Korea found novel associations implicating ATG16L2 and/or FCH and double SH3 domains protein 2 (FCHSD2) in CD [31]. Another novel potential susceptibility locus was identified at disks large homolog 1 (DLG1) in Chinese patients with CD [32].

\section{Diagnosis}

Difficult issues with regard to the diagnosis of IBD in Asian countries include limited access to medical facilities [4], a diversity of medical practice, including popular use of alternative and complementary medicine, together with a high background prevalence of infectious colitis and tuberculosis (TB) that may mimic IBD [11]. Therefore, it is of utmost importance to rule out infectious causes of colitis prior to making the diagnosis of IBD, especially in Asian nations. In difficult cases, interferongamma release assay and anti-Saccharomyces cerevisiae antibody (ASCA) may potentially be used as supplementary diagnostic tools given their high specificity for intestinal TB [33]. In certain cases, in which a definite diagnosis cannot be ascertained, a course of empirical anti-TB therapy may be initiated.

Diagnostic modalities in the East mostly resemble those of the West; Ileocolonoscopy with biopsies remains the gold standard. Small-bowel investigations for CD include small-bowel capsule and CT enteroclysis. However, many diagnostic tools available to the West, including magnetic resonance enterography, and non-invasive testing of biomarkers, such as faecal calprotectin, may not be widely available in many Asian centres managing IBD patients.

\section{Treatment and Management}

IBD therapies used in the West, including antibiotics, steroids, thiopurines, and anti-tumour necrosis factor alpha (anti-TNFa) agents, are also used in Asian nations. However, differing practices compared with the West may be present.

In a cross-sectional study comparing the management of IBD patients in Melbourne, Australia, and HK, it was shown that in Melbourne, steroids were used more at diagnosis, with more use of immunosuppressants, such as thiopurines or methotrexate, as compared with HK. For
Lui/Ng 
$\mathrm{CD}$, the use of anti-TNFa agents (39.9 vs. $11.0 \%$, p < 0.001 ) was more common in Melbourne than in HK. This was also true for UC, although only a small number of patients, 12 of 159 patients in Melbourne and 2 of 203 patients in HK were on these agents [14]. The underuse of anti-TNF $\alpha$ agents in Asia may be related to various factors, including clinicians' lack of experience with the therapy, high cost, lack of insurance reimbursement, and concern for opportunistic infections [34].

There is a major need for the use of anti-TNF agents in Asia given high rates of complex and severe disease; however, funding for such agents may not be widely available. Such consideration needs to be balanced against the cost of hospitalizations, surgery, outpatient visits and low work productivity.

As for the less frequent use of thiopurines, this may be restricted by limited experience in its use [35] and increased adverse effects that may be related to differences in thiopurine methyl-transferase (TPMT) polymorphisms in Asian patients [36]. Recently, a Korean group also discovered a single nucleotide polymorphism in NUDT15, which may partially explain the higher incidence of thiopurine-induced leukopenia in Asians [37]. In view of this, recommendations suggest the use of a lower starting dose of thiopurines in Asian patients and advocate the testing of TPMT and thiopurine metabolites [38], which are unfortunately not widely available in many Asia-Pacific regions.

In Japan, tacrolimus $[39,40]$ and leukocyte apheresis [41] are also widely used as second-line treatment in severe refractory UC [42].

Another special consideration in Asia is the screening of latent infections such as hepatitis B virus and TB prior to starting biologics. Thus, screening by hepatitis $\mathrm{B}$ virus serology and screening of TB by Mantoux or interferongamma release assay [43], prophylactic treatment if indicated and subsequent close monitoring are necessary to ensure the safe use of such agents [44].

\section{Prognosis}

There is a lower rate of colectomy for both UC and CD in Asian countries. The exact cause is not well known, but this may be due to cultural differences, a higher threshold for surgery in Asia or a milder disease course for UC subjects [9]. The natural disease course of patients with $\mathrm{CD}$ in Asia is not different from that of the West. Furthermore, a territory-wide study in the Chinese population showed that elderly-onset UC patients are increasing and

The Same Intestinal Inflammatory

Disease in the East and West? they have a higher risk of opportunistic infections, hospitalisation, colorectal cancer (CRC), and mortality than non-elderly-onset patients. Therefore, management and therapeutic strategies in this special group need special attention [45].

The incidence of CRC was also found to be much lower than in the West. A retrospective study from China noted that only around $0.4 \%$ of patients developed CRC [46], as compared to the overall incidence of CRC in UC of between 3 and 5\% in developed countries [47]. A lower incidence of CRC related to UC has also been reported from other Asian countries [7]. However, the follow-up period was short in the mentioned Chinese study [46], which may have minimised the ability to detect superimposed bowel malignancy as it is known that cancer is more likely to develop in patients with extensive colitis for 8 years or more [47]. It is likely that with increasing disease prevalence, the risk of CRC in UC in Asia will approach similar rates to that of the Western counterparts. Surveillance is necessary in these individuals with increased risk.

\section{Guidelines}

Frequently used guidelines in the West include the ECCO guidelines [48-53] and the American College of Gastroenterology guidelines [54, 55]. In the East, various countries have developed their own guidelines tailored for different patient needs. These include the Japanese guidelines [56], KASID (Korean) guidelines [57, 58], the Asia-Pacific consensus on UC and CD [38, 59, 60], and the Hong Kong Inflammatory Bowel Disease Society use of biologics consensus [61]. Broadly speaking, many of these guidelines are consistent with specific differences pertaining to each country such as the availability of drugs, the local risk of infections, regional standard clinical practice, local evidence, and opinions of regional experts.

\section{Conclusion}

Reliable epidemiologic data of IBD are emerging in the East and time trend data are needed to estimate the disease burden in the next decade. Although it is still a 'young' disease in Asia, in the next decade, the number of cases in Asia will likely approach that of the West considering the large background population, especially in countries like China and India. The cancer risk will likely 
increase over time given improved care and low disease mortality. Over time, this will have profound implications on the healthcare system. A multitude of environmental risk factors are likely to be involved, including the urbanisation of societies, changes in diet, antibiotic use, improved hygiene, microbial exposures, and pollution. A shared genetic risk for IBD is likely to be present across different populations, despite some genetic heterogeneity. The diagnosis and treatment of IBD in the East is similar to that in the West, but significant differences exist, such as the availability of drugs, cost of treatment, and differences in healthcare access. In the East, special considerations are necessary for latent infections and differentiating $\mathrm{CD}$ from intestinal TB continues to be a diagnostic challenge.

Education for patients, trainees, and physicians is important to tackle the foreseeable increase in disease burden in the near future. Healthcare policies would also need to take into account this rise in IBD, to provide mea- sures to improve the access to diagnostic tools and increase the availability of medications. In contrast to the West, there are also fewer surgeons and histopathologists who are specialising in IBD in Asia. A multidisciplinary approach to the management of IBD patients involving radiologists, surgeons, histopathologists, rheumatologists, dermatologists, IBD nursing specialists, and dietitians are also needed in the East. Last but not least, global collaboration in basic and clinical research would be important to provide locoregional data and recommendations to help healthcare providers and policymakers make informed decisions and policy changes to tackle the rising burden of IBD in Asia.

\section{Disclosure Statement}

The authors declare that there is no conflict of interest regarding this paper.

\section{References}

1 Ng SC, Tang W, Ching JY, Wong M, Chow CM, Hui AJ, Wong TC, Leung VK, Tsang SW, Yu HH, Li MF, Ng KK, Kamm MA, Studd C, Bell S, Leong R, de Silva HJ, Kasturiratne A, Mufeena MN, Ling KL, Ooi CJ, Tan PS, Ong D, Goh KL, Hilmi I, Pisespongsa P, Manatsathit S, Rerknimitr R, Aniwan S, Wang YF, Ouyang Q, Zeng Z, Zhu Z, Chen MH, Hu PJ, Wu K, Wang X, Simadibrata M, Abdullah M, Wu JC, Sung JJ, Chan FK; Asia-Pacific Crohn's and Colitis Epidemiologic Study (ACCESS) Study Group: Incidence and phenotype of inflammatory bowel disease based on results from the Asia-pacific Crohn's and colitis epidemiology study. Gastroenterology 2013;145:158-165e2.

2 Tan YM, Goh KL: Ulcerative colitis in a multiracial Asian country: racial differences and clinical presentation among Malaysian patients. World J Gastroenterol 2005;11:58595862.

- 3 Hilmi I, Singh R, Ganesananthan S, Yatim I, Radzi M, Chua AB, Tan HJ, Huang S, Chin KS, Menon J, Goh KL: Demography and clinical course of ulcerative colitis in a multiracial Asian population: a nationwide study from Malaysia. J Dig Dis 2009;10:15-20.

4 Prideaux L, Kamm MA, De Cruz PP, Chan FK, Ng SC: Inflammatory bowel disease in Asia: a systematic review. J Gastroenterol Hepatol 2012;27:1266-1280.

-5 Leong RW, Lau JY, Sung JJ: The epidemiology and phenotype of Crohn's disease in the Chinese population. Inflamm Bowel Dis 2004;10: 646-651.
6 Loftus EV Jr: Clinical epidemiology of inflammatory bowel disease: incidence, prevalence, and environmental influences. Gastroenterology 2004;126:1504-1517.

-7 Thia KT, Loftus EV Jr, Sandborn WJ, Yang SK: An update on the epidemiology of inflammatory bowel disease in Asia. Am J Gastroenterol 2008; 103:3167-3182.

8 Wang YF, Ouyang Q, Hu RW: Progression of inflammatory bowel disease in China. J Dig Dis 2010;11:76-82.

-9 Ng SC: Epidemiology of inflammatory bowel disease: focus on Asia. Best Pract Res Clin Gastroenterol 2014;28:363-372.

10 Ng SC, Bernstein CN, Vatn MH, Lakatos PL, Loftus EV Jr, Tysk C, O’Morain C, Moum B, Colombel JF; Epidemiology and Natural History Task Force of the International Organization of Inflammatory Bowel Disease (IOI$\mathrm{BD})$ : Geographical variability and environmental risk factors in inflammatory bowel disease. Gut 2013;62:630-649.

11 Ng SC: Emerging leadership lecture: Inflammatory bowel disease in Asia: emergence of a 'Western' disease. J Gastroenterol Hepatol 2015;30:440-445.

12 Asakura K, Nishiwaki Y, Inoue N, Hibi T, Watanabe M, Takebayashi T: Prevalence of ulcerative colitis and Crohn's disease in Japan. J Gastroenterol 2009;44:659-665.
13 Ng SC, Zeng Z, Niewiadomski O, Tang W, Bell S, Kamm MA, Hu P, de Silva HJ, Niriella MA, Udara WS, Ong D, Ling KL, Ooi CJ, Hilmi I, Lee Goh K, Ouyang Q, Wang YF, Wu K, Wang X, Pisespongsa $\mathrm{P}$, Manatsathit S, Aniwan S, Limsrivilai J, Gunawan J, Simadibrata M, Abdullah M, Tsang SW, Lo FH, Hui AJ, Chow CM, Yu HH, Li MF, Ng KK, Ching JY, Chan V, Wu JC, Chan FK, Chen M, Sung JJ; Asia-Pacific Crohn's and Colitis Epidemiology Study (ACCESS) Study Group: Early course of inflammatory bowel disease in a population-based inception cohort study from 8 countries in Asia and Australia. Gastroenterology 2016;150:86-95.e3.

14 Prideaux L, Kamm MA, De Cruz P, Williams J, Bell SJ, Connell WR, Brown SJ, Lust M, Desmond PV, Chan H, Chow DK, Wu JC, Leong RW, Sung JJ, Chan FK, Ng SC: Comparison of clinical characteristics and management of inflammatory bowel disease in Hong Kong versus Melbourne. J Gastroenterol Hepatol 2012;27:919-927.

15 Ouyang Q, Tandon R, Goh KL, Pan GZ, Fock KM, Fiocchi C, Lam SK, Xiao SD: Management consensus of inflammatory bowel disease for the Asia-Pacific region. J Gastroenterol Hepatol 2006;21:1772-1782.

16 Yang SK, Yun S, Kim JH, Park JY, Kim HY, Kim YH, Chang DK, Kim JS, Song IS, Park JB, Park ER, Kim KJ, Moon G, Yang SH: Epidemiology of inflammatory bowel disease in the Songpa-Kangdong district, Seoul, Korea, 1986-2005: a KASID study. Inflamm Bowel Dis 2008;14:542-549. 
17 Lakatos PL, Vegh Z, Lovasz BD, David G, Pandur T, Erdelyi Z, Szita I, Mester G, Balogh M, Szipocs I, Molnar C, Komaromi E, Golovics PA, Mandel M, Horvath A, Szathmari M, Kiss LS, Lakatos L: Is current smoking still an important environmental factor in inflammatory bowel diseases? Results from a population-based incident cohort. Inflamm Bowel Dis 2013;19:1010-1017.

18 Packard TG, Nguyen TV: East Asia Pacific At Work: Employment, Enterprise, and WellBeing. Washington, World Bank, 2014, pp xxxvi, 259.

-19 Sakamoto N, Kono S, Wakai K, Fukuda Y, Satomi M, Shimoyama T, Inaba Y, Miyake Y, Sasaki S, Okamoto K, Kobashi G, Washio M, Yokoyama T, Date C, Tanaka H; Epidemiology Group of the Research Committee on Inflammatory Bowel Disease in Japan: Dietary risk factors for inflammatory bowel disease: a multicenter case-control study in Japan. Inflamm Bowel Dis 2005;11:154-163.

20 Hou JK, Abraham B, El-Serag H: Dietary intake and risk of developing inflammatory bowel disease: a systematic review of the literature. Am J Gastroenterol 2011;106:563573.

21 Ng SC, Tang W, Leong RW, Chen M, Ko Y, Studd C, Niewiadomski O, Bell S, Kamm MA, de Silva HJ, Kasturiratne A, Senanayake YU, Ooi CJ, Ling KL, Ong D, Goh KL, Hilmi I, Ouyang Q, Wang YF, Hu P, Zhu Z, Zeng Z, Wu K, Wang X, Xia B, Li J, Pisespongsa P, Manatsathit S, Aniwan S, Simadibrata M, Abdullah M, Tsang SW, Wong TC, Hui AJ, Chow CM, Yu HH, Li MF, Ng KK, Ching J, Wu JC, Chan FK, Sung JJ; Asia-Pacific Crohn's and Colitis Epidemiology Study ACCESS Group: Environmental risk factors in inflammatory bowel disease: a populationbased case-control study in Asia-Pacific. Gut 2015;64:1063-1071.

22 Prideaux L, Kang S, Wagner J, Buckley M, Mahar JE, De Cruz P, Wen Z, Chen L, Xia B, van Langenberg DR, Lockett T, Ng SC, Sung JJ, Desmond P, McSweeney C, Morrison M, Kirkwood CD, Kamm MA: Impact of ethnicity, geography, and disease on the microbiota in health and inflammatory bowel disease. Inflamm Bowel Dis 2013;19:2906-2918.

-23 Machiels K, Joossens M, Sabino J, De Preter V, Arijs I, Eeckhaut V, Ballet V, Claes K, Van Immerseel F, Verbeke K, Ferrante M, Verhaegen J, Rutgeerts P, Vermeire S: A decrease of the butyrate-producing species Roseburia hominis and Faecalibacterium prausnitzii defines dysbiosis in patients with ulcerative colitis. Gut 2014;63:1275-1283.

24 Jostins L, Ripke S, Weersma RK, et al: Hostmicrobe interactions have shaped the genetic architecture of inflammatory bowel disease. Nature 2012;491:119-124.
25 Liu JZ, van Sommeren S, Huang H, et al; International Multiple Sclerosis Genetics Consortium; International IBD Genetics Consortium, et al: Association analyses identify 38 susceptibility loci for inflammatory bowel disease and highlight shared genetic risk across populations. Nat Genet 2015;47:979986.

26 Inoue N, Tamura K, Kinouchi Y, Fukuda Y, Takahashi S, Ogura Y, Inohara N, Nunez G, Kishi Y, Koike Y, Shimosegawa T, Shimoyama T, Hibi T: Lack of common NOD2 variants in Japanese patients with Crohn's disease. Gastroenterology 2002;123:86-91.

27 Guo QS, Xia B, Jiang Y, Qu Y, Li J: NOD2 3020insC frameshift mutation is not associated with inflammatory bowel disease in Chinese patients of Han nationality. World J Gastroenterol 2004;10:1069-1071.

28 McGovern DP, Kugathasan S, Cho JH: Genetics of inflammatory bowel diseases. Gastroenterology 2015;149:1163-1176.e2.

29 Asano K, Matsushita T, Umeno J, Hosono N, Takahashi A, Kawaguchi T, Matsumoto T, Matsui T, Kakuta Y, Kinouchi Y, Shimosegawa T, Hosokawa M, Arimura Y, Shinomura Y, Kiyohara Y, Tsunoda T, Kamatani N, Iida M, Nakamura Y, Kubo M: A genome-wide association study identifies three new susceptibility loci for ulcerative colitis in the Japanese population. Nat Genet 2009;41:1325-1329.

30 Ng SC, Tsoi KK, Kamm MA, Xia B, Wu J, Chan FK, Sung JJ: Genetics of inflammatory bowel disease in Asia: systematic review and meta-analysis. Inflamm Bowel Dis 2012;18: 1164-1176.

31 Yang SK, Hong M, Zhao W, Jung Y, Baek J, Tayebi N, Kim KM, Ye BD, Kim KJ, Park SH, Lee I, Lee EJ, Kim WH, Cheon JH, Kim YH, Jang BI, Kim HS, Choi JH, Koo JS, Lee JH, Jung SA, Lee YJ, Jang JY, Shin HD, Kang D, Youn HS, Liu J, Song K: Genome-wide association study of Crohn's disease in Koreans revealed three new susceptibility loci and common attributes of genetic susceptibility across ethnic populations. Gut 2014;63:8087.

32 Xu S, Zhou F, Tao J, Song L, Ng SC, Wang X, Chen L, Yi F, Ran Z, Zhou R, Xia B: Exome sequencing identifies DLG1 as a novel gene for potential susceptibility to Crohn's disease in a Chinese family study. PLoS One 2014; 9:e99807.

$33 \mathrm{Ng} \mathrm{SC}$, Hirai HW, Tsoi KK, Wong SH, Chan FK, Sung JJ, Wu JC: Systematic review with meta-analysis: accuracy of interferon-gamma releasing assay and anti-Saccharomyces cerevisiae antibody in differentiating intestinal tuberculosis from Crohn's disease in Asians. J Gastroenterol Hepatol 2014;29:1664-1670.

-34 Ng SC: Inflammatory bowel disease in Asia. Gastroenterol Hepatol (NY) 2013;9:28-30.

35 Sung JJ, Kamm MA, Marteau P: Asian perspectives in the management of inflammatory bowel disease: findings from a recent survey. J Gastroenterol Hepatol 2010;25:183-193.
36 Cao Q, Zhu Q, Shang Y, Gao M, Si J: Thiopurine methyltransferase gene polymorphisms in Chinese patients with inflammatory bowel disease. Digestion 2009;79:58-63.

37 Yang SK, Hong M, Baek J, Choi H, Zhao W, Jung Y, Haritunians T, Ye BD, Kim KJ, Park SH, Park SK, Yang DH, Dubinsky M, Lee I, McGovern DP, Liu J, Song K: A common missense variant in NUDT15 confers susceptibility to thiopurine-induced leukopenia. Nat Genet 2014;46:1017-1020.

38 Ooi CJ, Fock KM, Makharia GK, Goh KL, Ling KL, Hilmi I, Lim WC, Kelvin T, Gibson PR, Gearry RB, Ouyang Q, Sollano J, Manatsathit S, Rerknimitr R, Wei SC, Leung WK, de Silva HJ, Leong RW; Asia Pacific Association of Gastroenterology Working Group on Inflammatory Bowel Disease: The Asia-Pacific consensus on ulcerative colitis. J Gastroenterol Hepatol 2010;25:453-468.

-39 Ogata H, Matsui T, Nakamura M, Iida M, Takazoe M, Suzuki Y, Hibi T: A randomised dose finding study of oral tacrolimus (FK506) therapy in refractory ulcerative colitis. Gut 2006;55:1255-1262.

40 Ogata H, Kato J, Hirai F, Hida N, Matsui T, Matsumoto T, Koyanagi K, Hibi T: Doubleblind, placebo-controlled trial of oral tacrolimus (FK506) in the management of hospitalized patients with steroid-refractory ulcerative colitis. Inflamm Bowel Dis 2012;18: 803-808.

41 Hanai $\mathrm{H}$, Iida $\mathrm{T}$, Takeuchi $\mathrm{K}$, Watanabe F, Maruyama Y, Kageoka M, Ikeya K, Yamada M, Kikuyama M, Iwaoka Y, Hirayama K, Nagata S, Sato Y, Hosoda Y: Intensive granulocyte and monocyte adsorption versus intravenous prednisolone in patients with severe ulcerative colitis: an unblinded randomised multi-centre controlled study. Dig Liver Dis 2008;40:433-440.

42 Hida N, Nakamura S, Hahm KB, Sollano JD, Zhu Q, Rani AA, Syam AF, Kachintorn U, Ueno F, Joh T, Naito Y, Suzuki H, Takahashi S, Fukudo S, Fujiwara Y, Kinoshita Y, Uchiyama K, Yamaguchi Y, Yoshida A, Arakawa T, Matsumoto T; IGICS Study Group: A questionnaire-based survey on the diagnosis and management of inflammatory bowel disease in East Asian countries in 2012. Digestion 2014;89:88-103.

43 Wong SH, Ip M, Tang W, Lin Z, Kee C, Hung E, Lui G, Lee N, Chan FK, Wu JC, Sung JJ, Ng SC: Performance of interferon-gamma release assay for tuberculosis screening in inflammatory bowel disease patients. Inflamm Bowel Dis 2014;20:2067-2072.

$44 \mathrm{Hu}$ PJ: Inflammatory bowel disease in Asia: the challenges and opportunities. Intest Res 2015;13:188-190.
The Same Intestinal Inflammatory Disease in the East and West?
Inflamm Intest Dis 2016;1:78-84 DOI: $10.1159 / 000446625$ 
-45 Shi HY, Chan FK, Leung WK, Li MK, Leung CM, Sze SF, Ching JY, Lo FH, Tsang SW, Shan EH, Mak LY, Lam BC, Hui AJ, Wong SH, Wong MT, Hung IF, Hui YT, Chan YK, Chan $\mathrm{KH}$, Loo CK, Tong RW, Chow WH, Ng CK, Lao WC, Harbord M, Wu JC, Sung JJ, Ng SC: Natural history of elderly-onset ulcerative colitis: results from a territory-wide inflammatory bowel disease registry. J Crohns Colitis $2016 ; 10: 176-185$.

-46 Wang Y, Ouyang Q; APDW 2004 Chinese IBD Working Group. Ulcerative colitis in China: retrospective analysis of 3,100 hospitalized patients. J Gastroenterol Hepatol 2007; 22:1450-1455.

-47 Dobbins WO 3rd: Dysplasia and malignancy in inflammatory bowel disease. Annu Rev Med 1984;35:33-48.

- 48 Dignass A, Van Assche G, Lindsay JO, Lemann M, Soderholm J, Colombel JF, Danese S, D’Hoore A, Gassull M, Gomollon F, Hommes DW, Michetti P, O’Morain C, Oresland T, Windsor A, Stange EF, Travis SP; European Crohn's and Colitis Organisation (ECCO): The second European evidence-based Consensus on the diagnosis and management of Crohn's disease: current management. J Crohns Colitis 2010;4:28-62.

49 Van Assche G, Dignass A, Panes J, Beaugerie L, Karagiannis J, Allez M, Ochsenkuhn T, Orchard T, Rogler G, Louis E, Kupcinskas L, Mantzaris G, Travis S, Stange E; European Crohn's and Colitis Organisation (ECCO) The second European evidence-based Consensus on the diagnosis and management of Crohn's disease: definitions and diagnosis. J Crohns Colitis 2010;4:7-27.

50 Van Assche G, Dignass A, Reinisch W, et al; European Crohn's and Colitis Organisation (ECCO): The second European evidencebased Consensus on the diagnosis and management of Crohn's disease: special situations. J Crohns Colitis 2010;4:63-101.
51 Dignass A, Eliakim R, Magro F, Maaser C, Chowers Y, Geboes K, Mantzaris G, Reinisch W, Colombel JF, Vermeire S, Travis S, Lindsay JO, Van Assche G: Second European evidence-based consensus on the diagnosis and management of ulcerative colitis part 1: definitions and diagnosis. J Crohns Colitis 2012; 6:965-990.

52 Dignass A, Lindsay JO, Sturm A, Windsor A, Colombel JF, Allez M, D’Haens G, D'Hoore A, Mantzaris G, Novacek G, Oresland T, Reinisch W, Sans M, Stange E, Vermeire S, Travis S, Van Assche G: Second European evidence-based consensus on the diagnosis and management of ulcerative colitis part 2: current management. J Crohns Colitis 2012;6: 991-1030.

53 Van Assche G, Dignass A, Bokemeyer B, Danese S, Gionchetti P, Moser G, Beaugerie L, Gomollon F, Hauser W, Herrlinger K, Oldenburg B, Panes J, Portela F, Rogler G, Stein J, Tilg H, Travis S, Lindsay JO; European Crohn's and Colitis Organisation (ECCO): Second European evidence-based consensus on the diagnosis and management of ulcerative colitis part 3: special situations. J Crohns Colitis 2013;7:1-33.

54 Lichtenstein GR, Hanauer SB, Sandborn WJ; Practice Parameters Committee of American College of Gastroentorology: Management of Crohn's disease in adults. Am J Gastroenterol 2009;104:465-483; quiz 464, 484.

55 Kornbluth A, Sachar DB; Practice Parameters Committee of the American College of Gastroenterology: Ulcerative colitis practice guidelines in adults: American College Of Gastroenterology, Practice Parameters Committee. Am J Gastroenterol 2010;105:501523; quiz 524
56 Ueno F, Matsui T, Matsumoto T, Matsuoka K, Watanabe M, Hibi T; Guidelines Project Group of the Research Group of Intractable Inflammatory Bowel Disease subsidized by the Ministry of Health, Labour and Welfare of Japan and the Guidelines Committee of the Japanese Society of Gastroentorology: Evidence-based clinical practice guidelines for Crohn's disease, integrated with formal consensus of experts in Japan. J Gastroenterol 2013;48:31-72.

57 Ye BD, Jang BI, Jeen YT, Lee KM, Kim JS, Yang SK; IBD Study Group of the Korean Association of the Study of Intestinal Diseases. Diagnostic guideline of Crohn's disease (in Korean). Korean J Gastroenterol 2009;53: 161-176.

58 Choi CH, Kim YH, Kim YS, Ye BD, Lee KM, Lee BI, Jung SA, Kim WH, Lee H; IBD Study Group of the Korean Association of the Study of Intestinal Diseases: Guidelines for the management of ulcerative colitis (in Korean). Korean J Gastroenterol 2012;59:118-140.

59 Ooi CJ, Makharia GK, Hilmi I, et al; Asia Pacific Association of Gastroenterology (APAGE) Working Group on Inflammatory Bowel Disease: Asia Pacific Consensus Statements on Crohn's disease. Part 1: Definition, diagnosis, and epidemiology: (Asia Pacific Crohn's Disease Consensus - Part 1). J Gastroenterol Hepatol 2016;31:45-55.

60 Ooi CJ, Makharia GK, Hilmi I, et al; Asia Pacific Association of Gastroenterology (APAGE) Working Group on Inflammatory Bowel Disease: Asia-Pacific Consensus Statements on Crohn's disease. Part 2: Management. J Gastroenterol Hepatol 2016;31:5668.

61 Leung WK, Ng SC, Chow DK, Lao WC, Leung VK, Li MK, Hui YT, Ng SS, Hui AJ, Lai ST, Lam JT, Poon JT, Chan AO, Yuen H, Wu JC; Hong Kong IBD Society; Hong Kong IBD Society: Use of biologics for inflammatory bowel disease in Hong Kong: consensus statement. Hong Kong Med J 2013;19:61-68. 